DOI: https://doi.org/10.31933/dijemss.v2i3

Received: $3^{\text {rd }}$ December 2020, Revised: $15^{\text {th }}$ January 2021, Publish: $2^{\text {nd }}$ March 2021

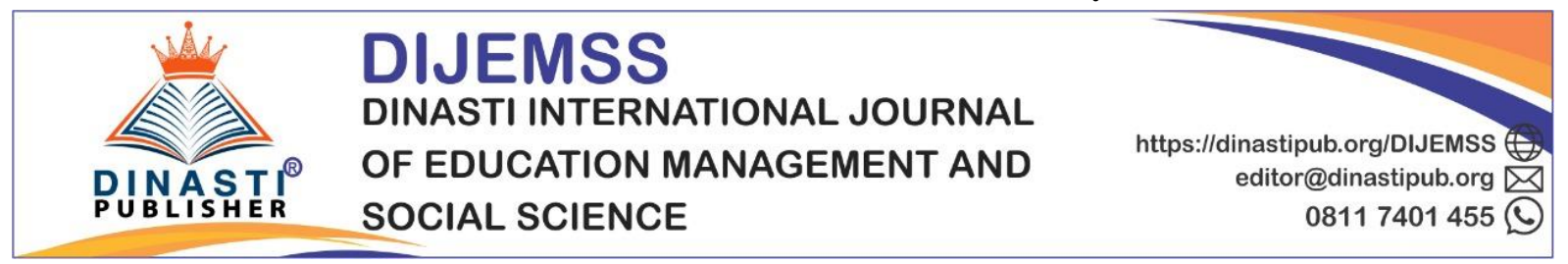

\title{
THE ROLE OF NGO's IN STRENGTHENING THE FARMER GROUPS (RESEARCH ON THE ROLE OF MERCY CORPS INDONESIA IN HUMBANG HASUNDUTAN DISTRICT)
}

\author{
Hendrik Sitanggang ${ }^{1}$, R.Hamdani Harahap ${ }^{2}$, Abdul Kadir ${ }^{3}$ \\ 1) Universitas Sumatera Utara, Sumatera Utara, Indonesia, drick.st2@gmail.com \\ ${ }^{2)}$ Universitas Sumatera Utara, Sumatera Utara, Indonesia, r.hamdani@usu.ac.id \\ 3) Universitas Sumatera Utara, Sumatera Utara, Indonesia.
}

Corresponding Author: Hendrik Sitanggang

\begin{abstract}
One of the problems in agriculture is the institutional problem of farmers who are not supportive. Non-Governmental Organizations can take a role in strengthening farmer groups, especially people in agricultural areas such as Humbang Hasundutan District. The purpose of this research is expected to provide in-depth information to describe and analyze activities conducted by Mercy Corps Indonesia in strengthening farmer group institutions. Research on the role of non-governmental organizations in instutional strengthening farmer group. This research uses qualitative methods. Researchers function as data collectors and analyzers related to the role of Mercy Corps Indonesia's non-governmental organizations in institutional strengthening farmer groups in Sinambela village at Humbang Hasundutan District. The results of this research were concluded several things, such as 1) Mercy Corps Indonesia Non-Governmental Organizations take a role in group strengthening farmers in Sinambela village, among them was through Livehood activities such as outreach activities, field meetings, making GAP (Good Demostration Practices) demonstration plots and strengthening the organization of farmer groups in Sinambela village. 2) Saolan and Haluaon farmer groups are slowly starting to strengthen from the dimension of organizational, human resources, finance, infrastructure and cooperation.
\end{abstract}

Keywords: Farmers Group, NGO, Role.

\section{INTRODUCTION}

Agricultural development basically includes the development and improvement of these factors: technology, natural resources, human resources and institutions (Uphoff, 1986; Johnson (1985) in Pakpahan, 1989). These factors are sufficient conditions to achieve the desired of development performance. Which means, if one or more of these factors are not available or cannot fulfill the criteria then it would be hard to achieve those certain desired performance. 
One of the obstacles in managing agricultural resources is the unsupportive agricultural institutions, among them was the farmer institution. According to this reason, it is necessary to develop farmer institutions based on the idea that:

1) The agricultural process requires tough human resources which supported by infrastructure, equipment, credit and etc.

2) Farmers' institutional development is more complicated than natural resource management because it requires supporting factors and production units.

3) Agricultural activities cover three acts: preparing inputs, converting inputs into products by labor and management efforts and placing outputs into value.

Agricultural activities requires support in the form of policies and institutions from central to local and Agricultural complexity that includes business and institutional units, which is very difficult to achieve on that optimal conditions.

Institutions are the whole of ideal patterns, organizations and activities which centered around basic needs such as family life, country, religion and obtaining food, clothing and enjoyment and shelter. An institution is formed always has purposes such as to meet various human needs so the institution has it functions. Besides, this institution is a concept which integrated all in structure, meaning that its not only involves in activity patterns which are born from social perspective to meet human needs, but also the organization patterns to doing it (Roucek and Warren, 1984).

The condition of the farmer groups from year to year could be said to have not experienced the development as expected or could be said to be constant or (even tending to decline). Most of the farmer group classes did not match the real situation. Even in Sinambela Village, there are farmer groups that always get assistance, even though the condition of these farmer groups is still not strong compared to other farmer groups in Sinambela Village (the role of farmer group management is very low, the group members were unclear, the organizational structure was incompleted and everything did not work according to its function, low business productivity and lack of guidance).

This condition was occured because those farmer groups were often used as a designated tool or container to provide assistance / subsidies related to government programs, therefore the formation and growth of farmer groups is mostly done because of projects and by the end of the project, the farmer groups would have no function or remain in name. Whereas these kind farmer groups could also develop mutual cooperation among the farmers. Gotong royong is doing work together with the same purpose and goals. Working together will make it easier for workers to get work completed and the desired goals achieved (R.Hamdani Harahap, 2020).

Non-governmental organizations could play role as an accelerating development. One of the pillars of development is increasing the independence of the community, especially those in agricultural areas that occured in Humbang Hasundutan Regency. Non-governmental organizations play a role in contributing as agents of development in society, strengthening communities and building community capacity. Based on the NGO role/NGO Mercy Corps Indonesia Foundation in Humbang Hasundutan which engaged in horticulture and rice agriculture, the author interest to see the role of these NGOs when carrying out their activities in the sector of strengthening farmer groups. The reason for choosing this sector because the author was observes and realizes that according to the data report from the Humbang 
Hasundutan Regency Agriculture Service, only 1/3 from the Humbang Hasundutan people joined the Farmer Group where there has the newest farmer groups $(91.4 \%)$ that need to be strengthened. The author realized this problem occurred due to the lack of institutional strengthening on farmer groups.

Mercy Corps Indonesia has a strong interest in strengthening the farmer groups so they will become strong farmer groups. Mercy Corps Indonesia began providing its assistance in April 2019 at the Saoloan Farmer Group and the Haluaon Farmer Group, Sinambela Village. The explanation above is the background when describing the role of Non-Governmental Organizations in strengthening the Farmers Group Institution at Humbang Hasundutan district.

The purpose of this research was expected to provide deep information about:

1) Describe and analyze the activities that carried out by Mercy Corps Indonesia in institutional strengthening of farmer group.

2) Describe and analyze the outcomes result from the activities that carried out and its impact towards institutional strengthening of farmer groups.

\section{RESEARCH METHODS}

Research Instruments In qualitative research, those research instruments or tools are the researchers themselves. Researchers are the key instrument, therefore in qualitative research the instrument is the person (human instrument). The research instrument is not external but internal, such as the researcher himself as an instrument (human instrument). Qualitative researchers as human instruments has a function to discover the focus of research, select informants as data sources, collect data, assess data quality, analyze data, interpret data and create the conclusions after their findings. Data analysis was carried out descriptively which presented in the form of a description, seen the relationship with one another and interpreted by exposure in the form of narration and description. Descriptive analysis was carried out on the information obtained through interviews and documentation.

\section{RESULT AND DISCUSSION}

The role is a set of expectations imposed on individuals who occupy certain social positions (David Berry, 1983). The role of Mercy Corps Indonesia could be seen from the expectations of the role holder which is, The Mercy Corps Indonesia towards the society or people whom associated with them while carrying out their roles or obligations.

The role of Mercy Corps Indonesia in realizing its hopes was done through activities in strengthening farmer groups including through the livelihood project, Farmer Group Organization and Administration.

\section{Livelihood}

Livelihood is an approach method in local economic empowerment to improve the welfare and quality of community livelihoods. Livelihood is carried out through activities in increasing agricultural products through counseling, field meetings, and making a Demonstration Plot (Demplot) with GAP (Good Agriculture Practices). Through the Livelihood activity, members of farmer groups would feel the benefits of farmer groups. That 
is because through this activity, farmer groups could increase their income from farming. Mercy Corps Indonesia (MCI) uses the Livelihoood strategy through these following stages:

1) Farmer group-based approach

Mercy Cops Indonesia provides an assistance that starting by reactivating routine farmer group meetings. Through farmer group meetings, Mercy Corps Indonesia provides counseling on strengthening farmer groups. These activities were carried out by socialization and training through farmer groups and promoting the good assisted farmer groups to the government in order to get their concerned.

Mercy Corps Indonesia never force the farmer groups to participate in these strengthening program. This is because it will have an impact on the sustainability of the program in the field. Because if forced, it will create an feeling of not belonging to these farmer group program. Mercy Corps Indonesia started with a pilot project, namely assisting 2 farmer groups who are willing to volunteer to be guided.

Mercy Corps Indonesia in every activity for beneficiaries always goes through farmer groups such as in providing counseling and field meetings related to shallot cultivation. In addition, this NGO also provides stimulants to the farmer groups. These stimulants are only stimulants so the farmers would feel motivated to carry out farmer group activities. This stimulation was also accompanied by a demonstration plot (pilot land) which facilitated by Mercy Corps Indonesia, so then those farmer groups have productive activities and gained such a benefit by joining the farmer groups compared to those who did not.

2) The thinking Change Process

Mercy Corps Indonesia started its program gradually by starting with these 2 (two) farmer groups willing to be helped in Sinambela Village. The roles played by Mercy Corps Indonesia in the process of changing the way of thinking of farmer groups include:

a) Training facility, pesticide stimulants and assistance for farmer group demonstration sites.

By assistance that carried out with technical partners (Pestisda Company) farmer groups were given intense understanding regarding the management of pests and plant diseases on target, on time and in an efficient manner.

Through regular monthly meetings, field meetings, counseling, and discussions via the WA Group which held by Mercy Corps Indonesia, farmer groups can understand the types of active pesticides that are appropriate for pest and plant disease management.

So far, this community has not received accurate information, either from PPLs or from farmer stalls that sell pesticides. People have been using this old method by only relying on the brand, not on the right active ingredients. The community or farmer groups have never known the pesticide company field officers, so farmers use pesticide products based on what they started decades ago, while pests and plant diseases were tough and resistant. Through these Demonstration Plots, farmer groups are given an understanding of changing good planting methods.

By regular assistance from Mercy Corps Indonesia and the Pesticide Company, the demonstration plot could increase shallot yields. The increase is that initially farmers 
produce a harvest of 1:10 (every $1 \mathrm{~kg}$ of dry onion seeds produces $10 \mathrm{~kg}$ of ready-to-sell onions), now they could produce 1:15 (every $1 \mathrm{~kg}$ of dry onion seeds produces $15 \mathrm{~kg}$ of ready-to-sell onions).

Table 1. Changes in the Improvement of Shallot Harvesting

\begin{tabular}{|c|c|c|c|c|}
\hline $\begin{array}{l}\text { Needs of seeds } \\
\text { per rante }\end{array}$ & $\begin{array}{l}\text { The need for } \\
\text { pesticides and } \\
\text { compost for } \\
\text { Shallots per rante }\end{array}$ & $\begin{array}{l}\text { Yield } \\
\text { comparison }\end{array}$ & Yield & $\begin{array}{l}\text { Market } \\
\text { selling price }\end{array}$ \\
\hline \multicolumn{5}{|c|}{ Prior to Mercy Corps Indon esia Assistan ces } \\
\hline $\begin{array}{l}30 \mathrm{Kg} \times \mathrm{IDR} \\
40,000 / \mathrm{Kg}=\mathrm{IDR} \\
1,200,000 / \mathrm{Kg}\end{array}$ & IDR 400,000 & $\begin{array}{l}\text { 1:10 (seedlings } \\
\text { : crop yields) }\end{array}$ & $300 \mathrm{Kg}$ & $\begin{array}{l}300 \mathrm{Kg} \times \text { IDR } \\
26,000=\mathrm{IDR} \\
7,800,000\end{array}$ \\
\hline \multicolumn{5}{|l|}{ After Assistances } \\
\hline $\begin{array}{l}30 \mathrm{Kg} \times \mathrm{IDR} \\
40,000 / \mathrm{Kg}=\mathrm{IDR} \\
1,200,000 / \mathrm{Kg}\end{array}$ & $\begin{array}{l}\text { IDR 1,000,000 } \\
\text { (Pesticide) + IDR } \\
100,000 \\
\text { (Fertilizer } \\
\text { Mabar/sak) = } \\
\text { IDR 1,100,000 }\end{array}$ & $\begin{array}{l}1 ; 15 \text { (seedlings } \\
\text { : crop yields) }\end{array}$ & $450 \mathrm{Kg}$ & $\begin{array}{l}450 \mathrm{Kg} \times \text { IDR } \\
26,000=\mathrm{IDR} \\
11,700,000\end{array}$ \\
\hline
\end{tabular}

b) Comparative Study

Mercy Corps Indonesia in the livelihood program in the field of horticultural cultivation has brought a farmer group from Humbang Hasundutan for comparative study to Mercy Corps Indonesia's assisted area, such as Subang district, West Java.

The comparative study was carried out for 5 days. Farmer group managers were selected to participate in this comparative study. The agenda of activities carried out during these comparative study are:

1. Farmer groups in Subang was discussed the challenges and progress of farmer groups with the Humbang Hasundutan Farmer Group.

2. Farmers' groups seen directly Good Agriculture Practices on farmer group land in Subang. So it could added the insight and skills of farmers to try apply it in Humbang Hasundutan Regency.

3. The Humbang Hasundutan farmer group was invited to see directly the farmer group's business units, such as the farmer's kiosk and the tractor rental business with the aim that the farmer group has an alternative source of cash for the group apart from basic and routine fees.

The business assistance of the Humbang farmer group did not stop at this comparative study, but Mercy Corps Indonesia followed up these results to Subang. From these 2 farmer groups in Sinambela village, only 1 farmer group, the Saoloan Farmer Group, has farmer group businesses, in the form of savings and loans and farmer kiosks.

c) The changing the way of thinking processed were also occurs through social interaction 
Social interaction is one of the factors which develops and changes in society, both in the farming community and society in general. Social interaction is a general form of social process. Social interaction is the key to all social life, there could be no life together.

For example, farmers outside the Mercy Corps Indonesia guidance, Mrs. Pelita Sinambela who implements plant cultivation techniques after conducting social interactions with farmers guidance by Mercy Corps Indonesia.

Mrs. Pelita Sinambela, when interviewed on November 10, 2020, said that she had never used chicken compost before, she's only uses chemical fertilizers. Farmers think that the land is still fertile like in the past when their parents planted shallots, so farmers did not use those mixture of compost as a basic fertilizer which has an impact on shallot yields which are not optimal.

After using that mixture of chicken compost and chemical fertilizers, it costs less to buy chemical fertilizers. Besides, chemical fertilizers were given indirectly, but were given by casting. Those prior habit applied to basic fertilizers by direct sowing.

3) Participation and capacity increase

Participation began with several members of farmer groups who were willing to take part in Mercy Corps Indonesia's activities through meetings, training, counseling and demonstration sites. The farmer groups participate in preparing the land and its processing, fertilizers and maintenance. Meanwhile, Mercy Corps Indonesia provides pesticide stimulants and technical assistance in agricultural cultivation. Participation of farmer groups were also measured by farmer group's monthly fees.

\section{Organization and Administration}

Apart from Livelihood activities, several types of findings from Mercy Corps Indonesia's mentoring activities in the Farmer Group in Sinambela Village are:

\section{1) Organization}

Initially, the farmer groups did not really respond to the importance of farmer group organization. This is because the farmer groups see that there are farmer groups that are not active but always get government assistance. This, of course, weakens other active farmer groups. However, Mercy Corps Indonesia explained that there will always be in any organization that has an $\mathrm{x}$ element outside of the norm. Mercy Corps Indonesia provides enthusiasm and explanations regarding the importance of organization in farmers groups. In addition to conducting organizational training, Mercy Corps Indonesia also promotes strong and independent farmer groups to the government so they could be noticed by the government.

Mercy Corps Indonesia has carried out organizational activities such as training and mentoring for group capacity building with the aim that the group has clear objectives and work programs, group administrators were be able to carry out their duties and responsibilities in a professional manner and farmer groups have statutes or rules of the game.

2) Farmers group administration 
Basically, Farmer Group that had not carried out good administrative records and did not understand the importance of administration within the farmer group. This could be seen in farmer group meetings, whereas farmer groups do not yet have a book attendance list for farmer group members, farmer group guest books, financial record books and records of each meeting. Mercy Corps Indonesia assistance, which is carried out through regular monthly meetings and training in farmer group administration to educate farmer groups on the importance of administration in farmer group institutions. Activities carried out include training and assistance in recording farmer group cash books, guest books, meeting attendance lists and notes on farmer group activity plans.

After Mercy Corps Indonesia assistance, the Saoloan and Haluaon Farmer Groups have recorded the farmer group cash books, where each recording is carried out in a transparent manner every month. Besides that, farmer groups also have attendance books, guest books and notes on farmer group activity plans.

\section{Institutional Strengthening Factors based on Deborah Eade Concept}

Regarding the role in this performance relationship, the role played by Mercy Corps Indonesia in carrying out its program refers to performance in strengthening farmer groups. Strengthening of farmer groups has factors that influence it. Deborah Eade (Mutiarin, 2014, p.182) were formulated which there are 5 dimensions of institutional strengthening, such as:

1) Organizational Dimension, which is the organization that has an organizational structure which could help carry out functions and achieve the organizational goals.

Basically the society wanted to join just because they could get subsidized fertilizer assistance from the government. This is a weakness for farmer group organizations, because farmer groups will not develop and cannot achieve the functions and goals of organizations as stated in the AD/ART.

That Interviews were related to farmer group organizations as conveyed by Pak Samsul Simanullang (Treasurer of the Saoloan Farmers Group and Secretary of Sinambela Village) on September 1, 2020 at his house in Sinambela Village: "After there is assistance from Mercy Corps Indonesia, the leadership of the management is strengthened. Formerly the motivation of farmers to join the farmer groups was only to get government subsidized fertilizer assistance, but after the guidance from Mercy Corps Indonesia, we learned more and more about the benefits of farmer group objectively". As a farmer group manager and village secretary, Mr. Samsul Simanullang said that most of his people wanted to join a farmer group because of the requirements to get government supports.

The Approval of institutional strengthening was also delivered by DPRD Member Humbang Hasundutan, Poltak Purba, ST. This DPRD member is the only one who came from Baktiraja District. He is also Commission B in charge of Agriculture, Tourism, etc. The support from DPRD members was conveyed during capacity training for farmer groups in Sinambela village and harvest thanksgiving events. "I am very supportive of these agricultural programs. The farmer groups should be independent, not only dependent on government support. I am ready to accept the aspirations from the community regarding agriculture because it is my department at DPRD Humbang Hasundutan". The presence of Mercy Corps Indonesia provides capacity training for 
farmer groups (Leadership, Organization and Farmer Group Business) and other assistance", said Mr. Poltak Purba, ST when interviewed on 27 October 2020 at the Pesona Tani Cooperative, Sinambela Village.

2) Human Resources Dimension, such as owning and developing human resources in quality and quantity through training or socialization. Human resource development activities through counseling which conducted by Mercy Corps Indonesia and PT Sygenta Indonesia have been felt by farmer groups as conveyed by members of farmer groups in an interview with Mr. Zaman Simanullang (Chairman of the Saoloan Farmer Group) on September 1, 2020 at his home in Sinambela Village. "Mercy Corps Indonesia provides training related to shallot plants, so then our shallot farming products are good and start to improve". The same thing was conveyed by Mrs. Berliana Limbong (Treasurer of the Haluaon Farmers Group) on September 1, 2020 at Mr. Samsul Simanullang's house in Sinambela Village: "The presence of Mercy Corps Indonesia is very beneficial. How to care for onion plants, we gained knowledge on how to plant through farmer groups as a forum for learning together". The results that were felt by the saoloan and haluaon farmer groups were an increase in the yield of shallots from the original one chain could produced $500 \mathrm{~kg}$ into 1 chain could produced $600 \mathrm{~kg}$ or an increase is about 20 percent.

3) Financial Dimension, which having a budget allocation in carrying out its functions and achieving organizational goals.

One way to increase group cash is to increase agricultural income and "trust" farmer group members to the financial management of farmer groups. This increase was carried out by increasing the knowledge and skills of onion plant cultivation by Mercy Corps Indonesia through farmer group meetings and field meetings at demonstration plots (demonstration plots) and skills training to increase farmer group capacity in administering group cash bookkeeping.

The results of interviews related to Mercy Corps Indonesia Assistance to Administration as conveyed by Omri Sinambela (Secretary of the Haluaoan Farmer Group) on September 2, 2020 at his home in Sinambela Village: "Mercy Corps Indonesia provides training related to group administration and bookkeeping. Our farmer groups were previously on hiatus but after the presence of Mercy Corps Indonesia, our group started to be active again (regular monthly fees and regular monthly meetings) and our program began to focus specifically on agriculture".

By the increase in income through good shallot cultivation and good group cash bookkeeping, members of farmer groups have routinely provided monthly fees because there is already "trust" from farmer group members in the financial management of farmer groups.

4) Infrastructure Dimension, which has the facilities and infrastructure in carrying out the functions and achieving organizational goals. One of the institutional strengthening of farmer group which carried out by Mercy Corps Indonesia is to provide stimulant saprotants (agricultural production facilities) in the form of pesticides (fungicides, insecticides, and acaricides) and shallot seeds (TSS) stamped arrowheads This stimulant only acts as an incentive by paying attention to farmers' self-help thereby the farmers also feel they owned the program. 
This was as conveyed by the PPL Coordinator (Mr. Ferdinan Simatupang) in an interview on October 27, 2020 at Pesona Tani Cooperative in Sinambela Village: "Mercy Corps Indonesia provides support to farmer groups in the form of saprotan assistance that could support farmer groups becomes strong". Based on him, a lot of saprotan assistance has been provided by the government (the agriculture service) to support agriculture in Baktiraja. Helps/stimulants from Mercy Corps Indonesia were also beneficial because apart from being given stimulants, they were also accompanied by technical personnel from input companies.

5) Cooperation Dimension, which is the organization that collaborating or coordinating with external parties from the organization. The institutional strengthening of farming which carried out by Mercy Corps Indonesia in this case is to enable farmer groups to collaborate/partnership with PT. Sygenta Indonesia in consulting the use of pesticides on target and effective and patnering with PT East West Seed (Red Panah) in terms related to the hybrid seeds and proper application of seed nurseries.

This is as conveyed by a member of the farmer group by Mr. Hermanto Tobing, S. Sos. (Member of the Haluaon Farmer Group) on September 1, 2020 at his house in Sinambela Village. "Previously, I didn't know that there was assistance like this that was done by Mercy Corps Indonesia to farmer groups. Mercy Corps Indonesia opens the mindset of farmer groups, Mercy Corps Indonesia is a sharing partner for farmer groups in agriculture because the role of PPL is not optimal here".

By increasing the total of networks, the farmer groups will be stronger because they have partners to share the obstacles / difficulties experienced which occurred from beginning to the end.

\section{CONCLUSION AND SUGGESTION Conclusion}

1) The NGO Mercy Corps Indonesia takes part in the Strengthening Activity of Farmer Groups in Sinambela Village, among others, through Livelihood activities in the form of counseling activities, field meetings, making demonstration plots as well as activities to Strengthen the organization and Administration of Farmer Groups in Sinambela Village.

2) The results of Mercy Corps Indonesia's NGO Assistance were included:

a) Farmer groups as a learning platform. Mercy Corps Indonesia has played a role in facilitating outreach, field meetings and assisting demonstration plots within farmer groups and has slowly changed the cultivation pattern of shallot plants. From these previous methods of controlling pests and diseases based on pesticide brands without paying attention to the active ingredients, now farmers have understood the benefits of using based on active ingredients in pesticides. So the farmer participation would began to increase in farmer group institutions as a place for learning.

b) Increased in income and improved the welfare. The Strengthening Program of the NGO Mercy Corps Indonesia which studied has brought lots of benefits in the form of increased income and improved levels of welfare. This is because Mercy Corps Indonesia provides technical training related to farming analysis, the use of pesticides in an appropriate way, sets on target and timely manner.

c) The institutionalization from the Saolan and Haluaon farmer groups is slowly starting to strengthen from the dimensions of Organization, Human Resources, Finance, 
Cooperation. There is partnership (cooperation) with technical partners, good administrative records of activities and financial administration, the organization of farmer groups has begun to be managed properly and farmer members had begun to realize the importance of strong farmer groups as a learning platform.

\section{Suggestion}

Some of suggestions that could be recommended based on this research are:

1) As for NGOs taking part in the community socio-economic empowerment sector. NGOs are expected to remain consistent with the essence of their existence and with their empowerment mission while continuing to increase the capacity of human and institutional resources in respond to the challenges of change and community needs.

2) As for the Government of Humbang Hasundutan district. It is expected to maintain the supportive-constructive partnerships with NGOs in the spirit of mutual learning and complementarity. From that, the society empowerment process could be carried out more effectively and accelerated

3) As for the residence of Humbang Hasundutan district. The community is expected to welcome every opportunity and empowerment programs which offered by the government and NGOs. Opportunities and empowerment programs from outside parties (NGOs and the Government) need to be supported by awareness and commitment from within oneself to change.

\section{REFERENCES}

Clark, John. (1995). NGO dan Pembangunan Demokrasi. Tiara Wacana. Yogyakarta.

David, B. (1983). Pokok-pokok pikiran dalam Sosiologi. Jakarta: Rajawali Pers.

Eldridge, P. J. (1995). Non-government organisations and democratic participation in Indonesia, Kuala Lumpur. New York: Oxford University Press.

Fakih, M. (2010). Masyarakat Sipil Untuk Transformasi Sosial, Pergolakan idiologi LSM Indonesia. Yogyakarta; Insist Press.

Hadi, A.P. (2010). Konsep Penguatan, Partisipasi dan Kelembagaan Dalam Pembangunan. Yayasan Agribisnis/Pusat Pengembangan Masyarakat Agrikarya (PPMA).

Harahap, R.H. Humaizi, \& Hasibuan, S.AF. (2020.) Traditional Wisdom of Batak Toba Community in Preserving Lake Toba Ecosystem In Samosir District and Dairi District, North Sumatera Province. Talent Development \& Excellence, 12(3s), 1842-1847.

Kartasasmita, G. (1996). Pembangunan Untuk Rakyat - Memadukan Pertumbuhan dan Pemerataan. Jakarta: PT. Pustaka CIDESINDO.

Mosher, A.T. (1987). Menggerakkan dan Membangun Pertanian. Syarat-Syarat Pokok Pembangunan dan Modernisasi. CV Yasaguna. Jakarta.

Ngalu, R. Yohannes, M. Jamun, \& Heronimus E. Wejang. (2019). Peran dan Strategi Lembaga Swadaya Masyarakat dalam Penguatan Sosial Ekonomi Masyarakat (Studi Kasus di Kabupaten Manggarai Nusa Tenggara Timur). Jurnal PKS, 18(3), 279-288. 
Uphoff, N. (1988). Menyesuaikan Proyek pada Manusia. dalam M.M. Cernea (eds). 1988. Mengutamakan Manusia di Dalam Pembangunan: Variabel-variabel Sosiologi di Dalam Pembangunan Pedesaan (Publikasi Bank Dunia). Penerjemah B.B. Teku. Jakarta: UI Press. 